\title{
En alvorlig underernært jente
}

\author{
Jenta ble innlagt i barneavdeling på grunn av alvorlig underernæring. \\ Hun hadde både gastrointestinale og nevrologiske symptomer, og årsa- \\ ken til den dårlige ernæringsstatusen var usikker.
}

En jente i tiårsalderen ble innlagt i barneavdeling på grunn av alvorlig underernæring. Hun var flyktning fra et afrikansk land. Familien var på flukt fra hjemlandet på grunn av krig. Jenta var ikke $i$ stand til å kommunisere verbalt ved innleggelsen, men ifølge moren hadde hun vært frisk frem til 3,5 år tidligere, da hun fikk feber og hoste. I Afrika hadde de oppsøkt lege som startet antibiotikabehandling, uten at dette hjalp. Jenta var nå alvorlig underernært og hadde den siste tiden utviklet symptomer i form av oppkast, spisevegring, svelgevansker og vektnedgang.

Hun ble innlagt i sykehus straks etter ankomst til Norge. Flere forskjellige årsaker til den alvorlige underernæringen ble initialt overveid, bl.a. tuberkulose og øvre gastrointestinal sykdom.

Pasienten hadde med seg håndskrevne journalnotater fra et afrikansk sykehus. Ifølge notatene hadde hun omtrent ett år tidligere hatt tynntarmsvolvulus og moderat gastroøsofageal refluks. Et halvt år senere ble hun operert med en tilstramming av den nedre øsofageale lukkemuskelen (Nissen-plastikk). Samtidig ble hun vurdert å være alvorlig underernært. Hun ble skrevet ut fra sykehuset med vitamintilskudd, men uten andre medisiner. Etter operasjonen fikk jenta mer besvær med å spise og klarte bare å innta flytende føde, som hun ofte kastet opp.

Ved ankomst til Norge var hun alvorlig underernært og medtatt. Hun fremsto som svært tynn - uten underhudsfett, med liten muskelmasse og utstående beinknokler. Hun klarte ikke à sitte uten støtte og hadde problemer med å stå. Hun var kald perifert og hadde rask puls - 130 slag per minutt. Det var normal saturasjon, men hun var blitt surklete $i$ pusten under transporten og hadde begynt å hoste. Hun veide $10,9 \mathrm{~kg}$, var $119 \mathrm{~cm}$ lang (BMI $\left.7,7 \mathrm{~kg} / \mathrm{m}^{2}\right)$ og hadde en overarmsomkrets på $10 \mathrm{~cm}$.

Verdens helseorganisasjon (WHO) definerer alvorlig underernæring som under tre standardavvik (Z-skår $<\div 3$ ) av vekt i forhold til høyde, og ifølge organisasjonens referanser er en overarmsomkrets $<11,5 \mathrm{~cm}$ også et tegn på alvorlig underernæring $(1,2)$. Jenta oppfylte begge disse kriteriene.
Ved alvorlig underernæring er det viktig at man primært stabiliserer pasienten og deretter overveier diagnostiske tiltak. Ifølge WHOs generelle prinsipper for behandling (ramme 1) skal man i første rekke unngå hypoglykemi, hypotermi og dehydrering (1-3). Pasienten skal i tillegg alltid dekkes mot mulig infeksjon, da infeksjonstegn ikke trenger å være tydelig til stede, grunnet svekket immunreaksjon (4).

Over hjertet hørtes en systolisk bilyd, og ved auskultasjon over lungene hørte man refererte slimlyder. Abdomen viste et arr etter bukkirurgi og var spent ved palpasjon, men uten palpable tumorer eller hepatosplenomegali. Hun hadde hvitt belegg på tungen som ga mistanke om oral candidainfeksjon, og det var en grå flekk på høyre cornea som kunne indikere xeroftalmi.

Det var uttalte nevrologiske symptomer nedsatt kraft i ekstremitetene, nedsatt koordinasjon, tremor $i$ hendene og nedsatt finmotorikk, og hun hadde også bulbære symptomer med dysfagi, dysartri og dysfoni. Jentas mentale tilstand var vanskelig å vurdere, men hun virket tilsynelatende adekvat og viste etter hvert at hun forsto hva moren sa.

Pasienten viste symptomer på vitamin Amangel ved å ha xeroftalmi. Utover mistanken om gastroøsofageal refluks og at hun var operert med Nissen-plastikk, hadde vi ingen klar årsak til underernæringen. Uansett bakenforliggende årsak la vi primært vekt på å stabilisere ernæringssituasjonen og gi henne standardisert anbefalt behandling for underernæring (2). Utover grunnleggende blodprøver, mikrobiologisk prøvetaking og enkel bildediagnostikk ble mer avansert diagnostikk avventet inntil videre.

CRP-nivået var $102 \mathrm{mg} / \mathrm{l}(<5 \mathrm{mg} /$ l), leukocytter $17,5 \cdot 10^{9} / \mathrm{l}\left(4,5-12,5 \cdot 10^{9} / \mathrm{l}\right)$ og nøytrofile celler $14 \cdot 10^{9} / \mathrm{l}\left(4,5-12,5 \cdot 10^{9} / \mathrm{l}\right)$. Blodprøvene viste for øvrig normal blodstatus - med normal verdier for $\mathrm{MCV}, \mathrm{MCH}$, jern og ferritin og noe lave retikulocytter på 19.1012/l (30-95 $\left.10^{12} / \mathrm{l}\right)$. Elektrolytter, leververdier, albumin, laktat, folat og vitamin $B_{12}$ var nor(37-63 $\mu \mathrm{mol} / \mathrm{l})$ - sannsynligvis pga. nedsatt muskelmasse. male, men kreatininnivået var lavt - $11 \mu \mathrm{mol} / \mathrm{l}$

\author{
Jakob Klcovansky \\ jakklc@ous-hf.no \\ Janne Kvammen \\ Barneklinikken \\ Oslo universitetssykehus, Ullevål \\ Monica Thallinger \\ Barneklinikken \\ Oslo universitetssykehus, Rikshospitalet \\ > Se kommentar side 314
}


Det ble tatt prøver på vitamin $D$, blodutstryk, tykk og tynn dråpe for malariautstryk, serologisk prøve på toksoplasmose, EpsteinBarr-virus, cytomegalovirus, hepatitt B-og hepatitt $C$-virus samt hivtest. Røntgen thorax var uten anmerkning og ultralyd abdomen var normal. Ekkokardiografi viste en fortykket mitralklaff med moderat lekkasje, uten stor hemodynamisk betydning.

Blodprøvene var overraskende upåvirket av jentas tilstand - sannsynligvis et resultat av langvarig sykdom og kompensatoriske mekanismer for å overleve på et meget lavt energiinntak. Ut fra anamnese gitt av moren var det ingen kjent tuberkulosekontakt, men familien hadde oppholdt seg under forhold hvor smitte kunne være mulig.

Vi diskuterte flere differensialdiagnoser som tuberkulose, hiv, Helicobacter pyloriinfeksjon, for stram Nissen-plastikk, dårlig kosthold samt flere tropiske sykdommer som leishmaniasis, schistosomiasis og innvollsorm. Ved uttalt underernæring ser man et generelt nedsatt immunforsvar, og det er svært vanskelig på et slikt stadium å utelukke potensielt alvorlige infeksjonssykdommer hos pasienten. Dette kalles ofte «nutritionally acquired immune deficiency syndrome» (NAIDS) (4).

Vi mistenkte også interkurrent luftveissykdom i forbindelse med flytransporten. I løpet av den første uken kunne vi ikke utelukke bakteriell eller parasittær infeksjon hos pasienten, og hun ble derfor dekket med bredspektret antibiotika og en dose antihelmintika. Bilyden over hjertet kunne være forårsaket av gjennomgått giktfeber og mitralinsuffisiens, men kunne også være sekundær til den alvorlige underernæringen.

Ifølge WHOs standardprotokoll for behandling av underernæring skal man samtidig med initial stabilisering av pasienten (dvs. unngå hypoglykemi, hypotermi og dehydrering) behandle akutte medisinske tilstander, dvs. elektrolyttforstyrrelser, infeksjoner og vitamin- og mineralmangel (2).

Vi startet umiddelbart behandling etter WHOs standardprotokoll for underernæring med tiamin, folat og høydose vitamin A. I tillegg fikk hun pabrinex lvitamin $C, B_{1}, B_{2}, B_{3}$ og $B_{6}$ l, vitamin $B_{12}$, vitamin $K$, kalium, sink og magnesium. På grunn av begynnende xeroftalmi fikk hun utvidet behandlingen med vitamin $A$.

Vi startet med oral Mycostatin mot oral candidiasis, og hun fikk cefotaksim i totalt sju dager på grunn av mistanke om interkurrent luftveisinfeksjon og som del av standardprotokoll. Albendazol ble gitt på sjuende dag. Pasienten fikk nasogastrisk sonde og vi startet med kontinuerlig ventrikkeldrypp med NAN2, som er den melkeerstatningen som likner mest på WHOs standardmelkeløsning F75 (2). Vi hadde ikke tilgang til F75 og laget sammen med ernæringsfysiolog en oversikt over alt innhold $i$ de forskjellige tilgjengelige ernæringsløsningene for å kunne lage en melkeløsning lik F75.

På grunn av jentas betydelig reduserte allmenntilstand ble hun initialt isolert på barneintensiven og ble etter tre dager flyttet til isolat på barnemedisinsk infeksjonspost. Hun fikk kontinuerlig ventrikkeldrypp i til sammen sju dager. Vi skiftet deretter over til Nutrini i gradvis opptrappende mengder. Etter ytterlige tre dager var hun over på $100 \%$ Nutrini.

WHOs standardprotokoll omfatter flere faser i behandling av underernæring (2). Den initiale stabiliseringsfasen med akuttbehandling av infeksjoner og mangelsykdommer (fase 1) varer ofte i 1-7 dager. I denne fasen får pasienten $100 \mathrm{kcal} / \mathrm{kg} / \mathrm{dag}, 1-1,5 \mathrm{~g}$ protein $/ \mathrm{kg} /$ dag samt $130 \mathrm{ml}$ væske/kg/dag. Ernæringen er saltfattig, men har høyt kalium-, fosfat-, sink- og magnesiuminnhold. Etter stabiliseringsfasen kommer en 1-3 dagers transisjons- eller overgangsfase, hvor man suksessivt trapper opp til $150 \mathrm{kcal} / \mathrm{kg} / \mathrm{dag}$ (3). Neste fase heter rehabiliteringsfasen (fase 2), der man sikter mot ca. $200 \mathrm{kcal} / \mathrm{kg} / \mathrm{dag}$. En rask kontrollert vektøkning på ca. $10 \mathrm{~g} / \mathrm{kg} / \mathrm{dag}$ er ønskelig (2).

Ernæringen starter ofte via en nasogastrisk sone med små, hyppige måltider. WHO anbefaler initialt sin egen F75-løsning (75 kcal/ $100 \mathrm{ml})$, deretter overgang til F100 (100 kcal/ $100 \mathrm{ml}$ ) i fase 2. Vi brukte initialt NAN2 $(67 \mathrm{kcal} / 100 \mathrm{ml})$ i fase $1 \mathrm{og}$ Nutrini Multifiber $(100 \mathrm{kcal} / 100 \mathrm{ml}) \mathrm{i}$ fase 2 . Da både NAN2 og Nutrini inneholder mindre kalium, magnesium og flere andre sporstoffer enn WHOs egne løsninger, fikk vår pasient ekstra tilskudd av disse emnene.

Etter fem dager startet vi med protonpumpehemmer pga. mistanke om sykdom relatert til gastroøsofageal refluks. Etter en uke seponerte vi cefotaksim og Mycostatin. Da vi ikke kunne utelukke gjennomgått revmatisk feber, startet vi deretter med forebyggende antibiotika i form av penicillin.

På dag 7 ble det gjort CT thorax, som viste flere forkalkede lymfekjertler i det aortopulmonale vindu og i høyre hilus (fig 1) samt en forkalkning $i$ venstre overlapps basalfelt som kunne representere Gohns fokus, altså et tuberkuløst primærkompleks (fig 2). Man så sentrale sakkulære bronkieektasier, mest $i$ høyre lunge, samt tynne atelektatiske fortetninger langs fissura major $i$ venstre lunge, men ingen infiltrater eller kaverner. Oesophagus var dilatert $i$ hele sin lengde med uttalt trang overgang til ventrikkelen.

På grunn av pasientens nevrologiske sym-

\section{RAMME 1}

WHOs generelle prinsipper

for behandling av underernæring (2)

Unngå/behandle hypoglykemi

Unngå/behandle hypotermi

Unngå/behandle dehydrering

Korrigere elektrolyttubalanse

Unngå/behandle infeksjoner

Korrigere mangel på vitaminer og sporstoffer

Begynn forsiktig ernæring

Etterstrebe opphentingsvekst (catch-upvekst)

Gi barnet sensorisk stimulering og emosjonell støtte

Forbered oppfølging når barnet er blitt friskt

ptomer ble det gjort MR caput, som var normal. Som en del av utredningen av mistenkt tuberkulose ble det utført en IGRA-test (Interferon Gamma Release Assay) (Quantiferon TB Gold), som viste $0,15 \mathrm{IU} / \mathrm{ml}(<0,35 \mathrm{IU} / \mathrm{ml}$ ) med lav positiv kontroll (mitogenkontroll). Det var spørsmål fra laboratoriet om pasienten var immunsupprimert. Det ble ikke påvist mykobakterier i gastrisk aspirat.

Selv om funnene på CT thorax var mest forenlig med tidligere gjennomgått tuberkulose, kunne vi ikke utelukke aktiv sykdom. IGRAtesten var negativ, men det faktum at den viste lav mitogenkontroll, kunne peke i retning av at pasienten hadde nedsatt immunforsvar, noe som var sannsynlig på grunn av den alvorlige underernæringen.

Vi besluttet derfor etter 13 dager å starte standard tuberkulosebehandling med rifampicin, isoniazid, pyrazinamid og etambutol i to måneder etterfulgt av rifampicin og isoniazid i fire måneder.

Prøvene for leishmaniasis, schistosomiasis og innvollsormer var negative. Serologiske prøver viste gjennomgått cytomegalo- og Epstein-Barr-virusinfeksjon, men det var negative serologiske prøver når det gjaldt toksoplasmose, hepatitt B-og hepatitt $C$-virus samt negative hiv- og syfilistester. $H$. pyloriIgG var positiv.

Etter 20 dager hadde pasienten gått opp fra $10,9 \mathrm{~kg}$ til $13,4 \mathrm{~kg}$, det tilsvarer en vektøkning på $23 \%$ (fig 3). Økningen i kaloriinntak gikk etter planen, og pasienten gikk opp i vekt som forventet.

CT thorax hadde gitt mistanke om trang Nissen-plastikk, samtidig hadde pasienten 


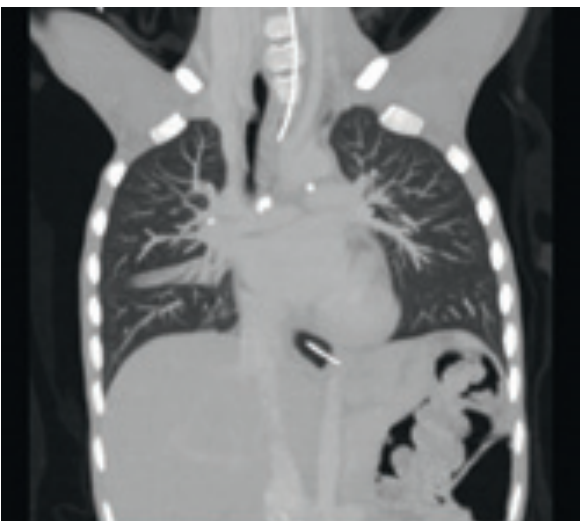

Figur 1 Forkalkede lymfeglandleridet aortopulmonale vindu

reagert med kraftig oppkast på forsøk med peroral ernæring og overgang til sondemåltider. På bakgrunn av dette besluttet vi å fortsette med kontinuerlig sondeernæring. Etter seks uker anså vi pasienten som sterk nok til å gjennomgå narkose, og det ble gjort en oesophagusduodenoskopi. Denne viste upåfallende mucosa i oesophagus, som dog var stor og betydelig dilatert med en trang overgang til ventrikkelen gjennom den nedre øsofageale lukkemuskelen.

Ventrikkelslimhinnen var upåfallende, men også pylorus var trang og smal og viste en «blokkeffekt» ved gjennomgang av skopet. Biopsier viste sannsynlig H. pylori-gastritt, og pasienten fikk eradikasjonskur med

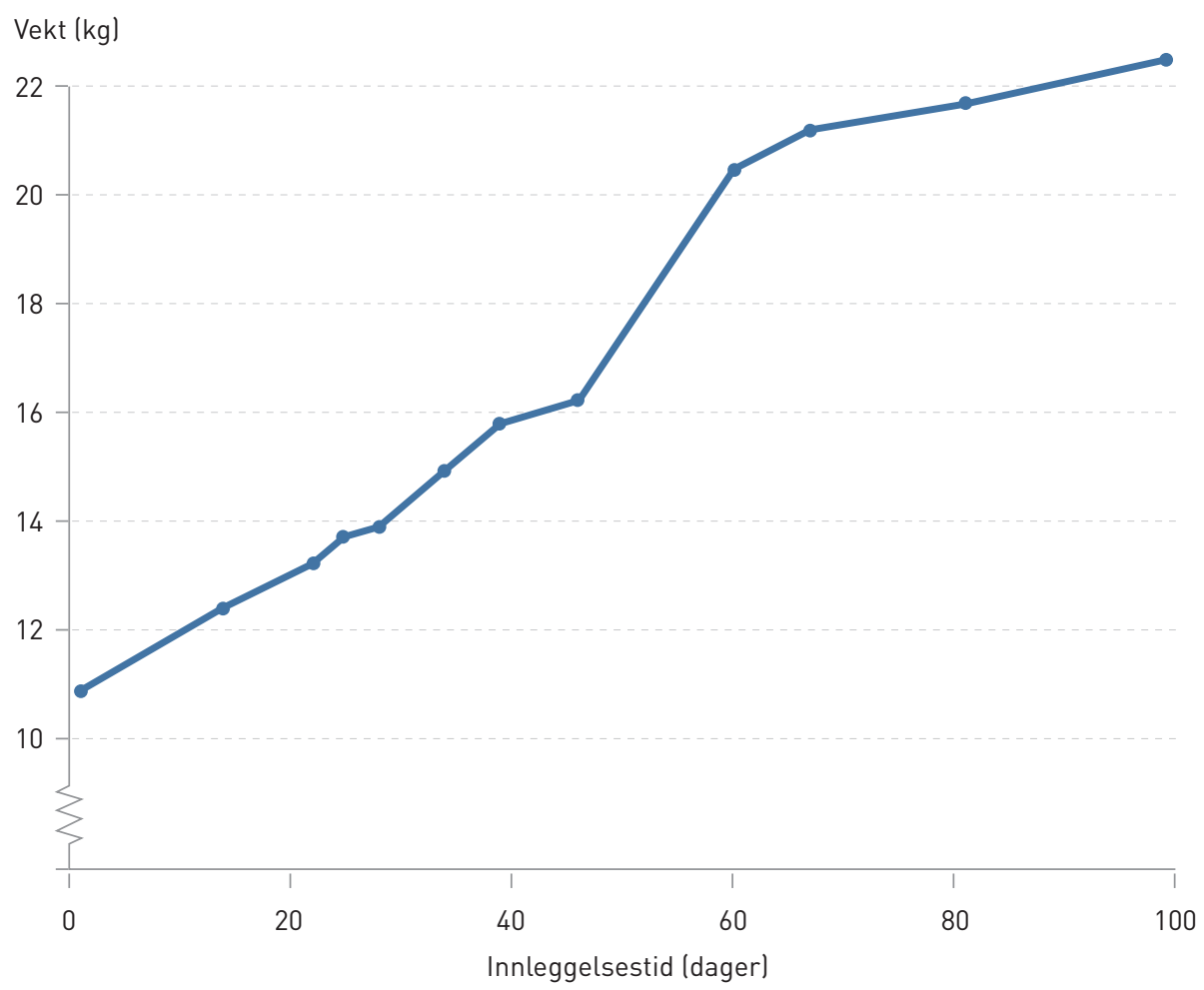

Figur 3 Pasientens vektutvikling under innleggelsen. Dag 0 tilsvarer innleggelsesdagen

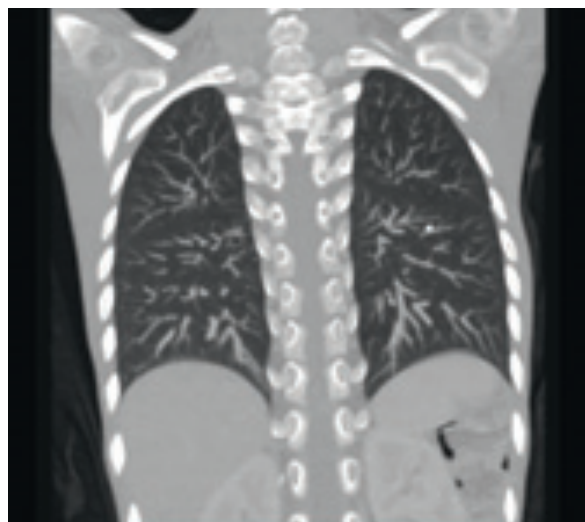

Figur 2 Suspekt primærfokus (Gohns fokus) basalt ivenstre overlapp

amoksicillin og klaritromycin i 14 dager. Det ble også gjort kontrastrøntgen av oesophagus, ventrikkel og duodenum, som viste god passasje av kontrastvæske. En 24timers $\mathrm{pH}$-måling og ventrikkeltømmingstest var normale. Svelgefilming viste at drøyt halvparten av væsken pasienten svelget havnet $i$ lungene, og høyoppløsningsmanometri viste et konstant forhøyet trykk i den nedre øsofageale lukkemuskelen. Dette forsterket mistanken om for stram Nissenplastikk.

Etter to måneder ble det gjort nevrografi, som viste uttalt sensorisk-motorisk polynevropati, og SEP-test (sensory evoked potential) av n. medianus bekreftet nedsatt nerveledningshastighet. Konklusjonen var at pasienten hadde sensorisk polynevropati, sannsynligvis på grunn av vitaminmangel og dårlig ernæringsstatus over lang tid.

Etter flere diskusjoner med infeksjonsmedisinere, gastroenterologer og barnekirurger konkluderte vi med at jenta sannsynligvis var blitt operert med en for stram Nissenplastikk. Dette kunne være årsaken til symptomforverring med gulping og svelgebesvær etter gjennomgått operasjon den foregående vinteren.

Hva som eventuelt var underliggende sykdom før dette, var fortsatt usikkert, men noen ledetråder hadde vi fått. Vi kunne konstatere at hun tidligere hadde gjennomgått tuberkulose, som kunne være spontankurert, latent eller aktiv. I tillegg hadde hun en H. pylori-gastritt. Det var ikke mulig å bekrefte at disse infeksjonene var årsak til hennes sykdom, men det var teoretisk mulige og sannsynlige forklaringer.

Jenta hadde ved utskrivning etter over tre måneders innleggelse fortsatt problemer med måltider via sondeernæring og måtte få dette i kontinuerlig drypp. Hun veide $22 \mathrm{~kg}$ ved utskrivning, og vekten var da fordoblet. Hun ble skrevet ut til hjemmet for så å komme på et habiliteringssenter for barn og unge, der hun skulle få hjelp til svelging og generell motorikk.

Man valgte å utsette eventuell kirurgisk korreksjon av Nissen-plastikken til hun hadde fått bedre nevrologisk funksjon. Hun har hatt poliklinisk oppfølging av barnegastroenterolog, nevrolog og ernæringsfysiolog. Tuberkulosebehandlingen ble gjennomført med direkte observert behandling (DOT) av hjemmesykepleien.

\section{Diskusjon}

Underernæring er en vanlig problemstilling som helsepersonell møter i den tredje verden. Den mest utsatte pasientgruppen er barn under fem år, og WHO estimerer at underernæring står for nærmere en tredel av mortaliteten i denne gruppen i verden som helhet (5). I Skandinavia ser vi sjelden barn med alvorlig underernæring, bortsett fra pasienter med diagnosen anoreksi eller noen ganger hos barn med alvorlige funksjonshemninger og underliggende sykdommer.

Årsakene til underernæring er kompleks og multifaktorielle. Tilstanden er ofte resultat av lavt kaloriinntak og mat av dårlig kvalitet, men kan være sekundær til sykdom samt skyldes kulturelle faktorer og ytre faktorer som for eksempel krig og hungersnød (6).

Undernæring kan være akutt eller kronisk. Det finnes tre hovedformer av alvorlig underernæring: marasmus, kwashiorkor og blandingstilstanden marasmisk kwashiorkor. 
Kwashiorkor kjennetegnes av tynn, skrumpet hud, pigmenttap, håravfall, oppsvulmet buk og hevelser på underekstremitetene. Marasmus, på den annen side, kjennetegnes av at pasienten mangler underhudsfett, har muskelatrofi, gammelmannsansikt med innhule kinn, lite periorbitalt fett, løs hud og stor mage (1).

Vår pasient ble klinisk vurdert å ha en marasmisk tilstand og oppfylte flere kliniske tegn på denne diagnosen. Hun var lav av vekst i forhold til alderen (kortvoksthet, «stunting»), dette passet med at underernæringen hadde vedvart over en lang periode og var blitt kronisk.

Det skjer en rekke fysiologiske og patofysiologiske forandringer $\mathrm{i}$ kroppen når for lite næring blir tilført. Vår pasient hadde en marasmisk tilstand på grunn av kronisk alvorlig underernæring - kroppen hennes tilpasset seg et lavt kaloriinntak over en lang periode. Hos slike pasienter blir hjertets minutt- og slagvolum ofte redusert, og de har gjerne lavt blodtrykk. Intravenøst tilskudd av natriumklorid kan lede til kraftig forhøyet sentralvenøst trykk, som kan gi kardial overbelastning og hjertesvikt (4). Derfor gjenopprettet vi væskebalansen hos jenta med forsiktig peroral rehydrering. Intravenøs væske må kun gis på streng indikasjon, som f.eks. ved manifest sjokk.

Etter en så lang periode med lavt kaloriinntak og nedsatt passasje av ernæring i tarmene var jentas gastrointestinale motilitet redusert. Pancreas er hos slike pasienter ofte atrofisk, og nedsatt insulinsekresjon leder ofte til redusert glukoseintoleranse samtidig som glukoneogenesen er mindre effektiv og pasienten lett blir hypoglykemisk. Tarmabsorpsjonen kan være nedsatt på grunn av atrofisk tynntarmsslimhinne, og man finner ofte bakteriell overvekst i tarmlumen, noe som kan lede til diaré. Levermetabolismen er ofte påvirket, og hepatotoksiske medisiner som f.eks. paracetamol bør ikke gis (4).

Vår pasient hadde initialt vansker med temperaturreguleringen. Underernærte barn blir ofte poikiloterme, noe som innebærer at de lettere blir hypoterme når det er kaldt og hyperterme når det er varmt. Kreatininnivået hos jenta var lavt, sannsynligvis på grunn av liten muskelmasse, men den renale perfusjonen hos slike pasienter er i tillegg ofte redusert og i dette stadiet er pasientene ekstremt følsomme for natriumoverskudd i både kost og intravenøs væske (4).

Jentas immunsystem var kraftig supprimert, og hos kraftig underernærte pasienter ser man sjelden inflammasjon og leukocyttmigrasjon ved vevsskade, dermed heller ikke pussdanning. Man ser også sjelden feber eller leukocytose ved infeksjoner. Lokaliserte infeksjoner (f.eks. lobær pneumoni) er uvanlig. Man ser i stedet diffuse infeksjoner (f.eks. bronkopneumoni). Bredspektret antibiotika bør administreres liberalt til alle barn som legges inn med alvorlig underernæring og komplikasjoner.

Na-/K-pumpen er mindre effektiv, og intracellulært er det forhøyet nivå av natrium og lave nivåer av kalium, magnesium og fosfat. Etter hvert som vår pasient langsomt ble bedre og økte energiinntaket, ble $\mathrm{Na}$-/K-pumpen mer effektiv og natrium ble pumpet ut av cellene og kalium pumpet inn. Det var da viktig å gi henne næring med lavt saltnivå og høyt kaliumnivå. Dersom pasienten har ødemer, transporteres natrium og væske fra interstitiet inn i blodbanen. Skjer dette for raskt etter start av enteral ernæring, før nyrene har fått tilbake normalfunksjonen, kan det lett lede til kardial overbelastning og hjertesvikt (4).

WHO estimerte i 2011 at 165 millioner barn under fem år lider av underernæring (6). Hos mange av disse er tilstanden så alvorlig at de trenger sykehusbehandling, men på noen sykehus er mortaliteten så høy som $30-50 \%$. Om man følger WHOs retningslinjer for behandling, kan mortaliteten reduseres til $<5 \%(5)$.

Alvorlig underernæring er en medisinsk akuttilstand hvor man primært skal unngå hypotermi, hypoglykemi og infeksjoner. Samtidig må man langsomt gjenopprette barnets normale fysiologiske funksjoner. $\AA$ gjøre dette aggressivt - med høyproteindietter, diuretika ved ødemer og saltholdige væsker intravenøst for korreksjon av elektrolyttdefekter - kan være direkte fatalt (4).

Pasienten og pasientens foreldre har gitt samtykke til at artikkelen blir publisert.

Vi takker overlege Per-Kristian Knudsen for gjennomlesing og verdifulle kommentarer og overlege Behzad Khoshnewiszadeh for vurdering av bildediagnostikken.

\section{Jakob Klcovansky (f. 1980)}

er lege i spesialisering i pediatri.

Forfatter har fylt ut ICMJE-skjemaet og oppgir ingen interessekonflikter.

\section{Janne Kvammen (f. 1972)}

er klinisk ernæringsfysiolog,

Forfatter har fylt ut ICMJE-skjemaet og oppgir ingen interessekonflikter.

\section{Monica Thallinger (f. 1979)}

er lege i spesialisering i pediatri. Hun arbeider for Leger uten grenser.

Forfatter har fylt ut ICMJE-skjemaet og oppgir ingen interessekonflikter.

\section{Litteratur}

1. Kliegman RM, Behrman RE, Jenson HB et al. Nelson Text book of pediatrics. Undernutrition. 18 utg. Philadelphia, PA: Saunders, 2007.

2. Ashworth A, Khanum S, Jackson A et al. Guidelines for the inpatient treatment of severely malnourished children. WHO-report. Genève: WHO 2003

3. Golden MH, Grellety Y. Guidelines for the management of the severely malnourished. New York, NY: ACF International, 2006.

4. Golden MH. Management of severe malnutrition: a manual for physicians and other senior health workers. WHO-report. Genève: WHO, 1999

5. You D, New JR, Wardlaw T et al. Levels and trends in child mortality. WHO-report. Genève: WHO 2012

6. World Health Organization. Water-related diseases: malnutrition. www.who.int/water sanitation health/ diseases/malnutrition/en/ (1.2.2013).

Mottatt 1.3. 2013, første revisjon innsendt 3.7. 2013, godkjent 3.10. 2013. Redaktør: Sigurd Høye. 